\title{
Trees spit out gas from soil microbes
}

The atmospheric concentration of methane, a greenhouse gas with 25 times the heating power of carbon dioxide, has more than doubled over the past 200 years. Researchers have long known that methane comes from anaerobic processes in waterlogged soils such as swamps, wetlands and rice fields, as well as in the guts of termites and ruminant animals such as cows and sheep. But in 2006, a team proposed the surprising idea ${ }^{1}$ that plants, too, produce methane - as much as $10-30 \%$ of the world's total methane emissions. If true, that would require a major overhaul of global carbon budgets.

Now a study suggests that trees can act like chimneys, moving methane gas produced by soil microbes up through roots, stems and leaves before releasing it into the atmosphere. This effect could account for as much as $10 \%$ of methane emissions globally ${ }^{2}$. It could also help to explain why methane fluxes are higher than expected in wet tropical regions.

Ellen Nisbet, an evolutionary biologist at the University of South Australia in Adelaide, previously reported that plants do not have the biochemical pathways needed to generate methane. "I'm pretty sure from our studies that [plants] aren't making methane themselves," she says. "This paper is really showing that methane is moving around the plants, that it's being transported up and out."

The team responsible for the latest work, led by atmospheric scientist Andrew Rice of Portland State University in Oregon, measured methane flow in three tree species, which were flooded to create conditions ripe for anaerobic microbes to start churning out methane.

Rice says that the work does not rule out

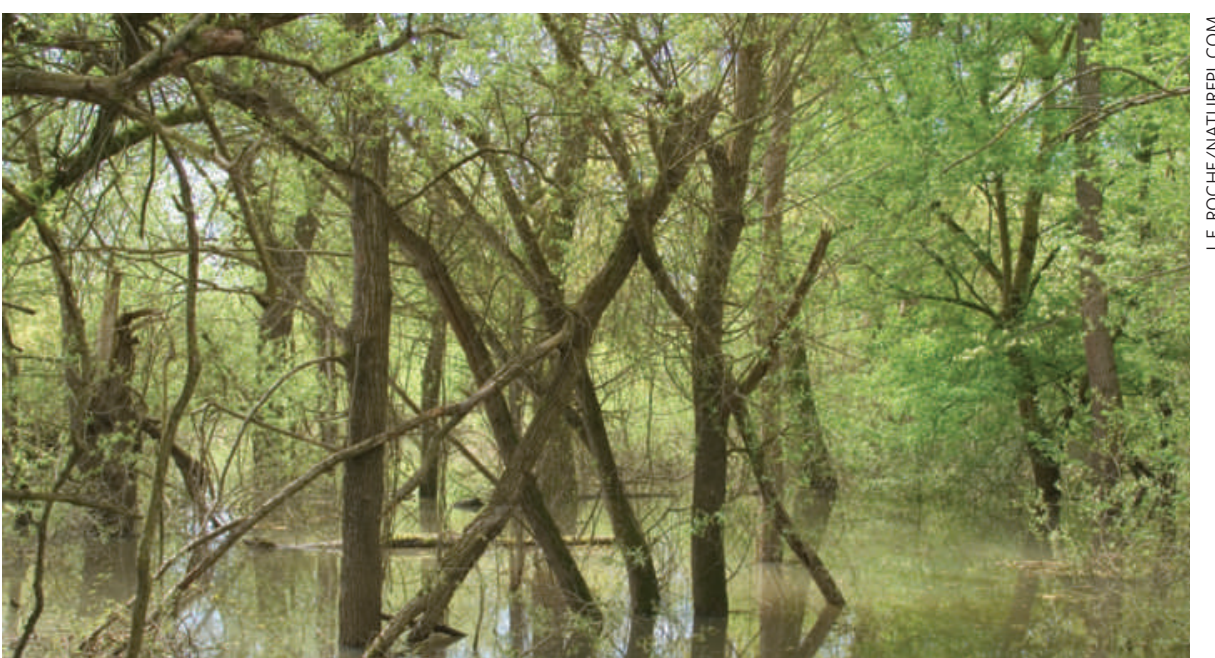

Waterlogged soils provide the perfect environment for methane-producing soil bacteria.

the possibility that plants themselves can produce methane aerobically; for instance, light at a certain intensity and wavelength could create a photolytic reaction that produces methane, as the 2006 work suggested. "The question is the magnitude of that source," says Rice.

The latest study also found that the isotopic composition of the microbial methane transported through the trees was almost identical to that of the methane emissions observed in the 2006 study. This means that it could be tough to distinguish in the field between methane produced anaerobically and that produced aerobically.

The idea of aerobic methane production "is still a hard pill for a lot of scientists to swallow", says Patrick Megonigal, a biogeochemist at the Smithsonian Environmental Research Center in
Washington DC. “This paper shows that there are other mechanisms that we understand a little better, which could give you the same isotopic ratio and fit into the budget nicely."

The team leader of the original paper says he remains confident that plants are making their own methane, although soils clearly also contribute. "It's getting clearer that living vegetation is maybe playing a more active role in emitting methane to the atmosphere than we previously thought," says Frank Keppler, a geochemist at the Max Planck Institute for Chemistry in Mainz, Germany. Amanda Mascarelli

\footnotetext{
1. Keppler, F., Hamilton, J. T. G., Braß, M. \& Röckmann, T. Nature 439, 187-191 (2006).

2. Rice, A. L. et al. Geophys. Res. Lett.

doi:10.1029/2009GL041565 (2010)

3. Nisbet, R. E. R. et al. Proc. R. Soc. B 276, 1347-1354 (2009)
}

Physics, builds on a well-established idea. Global temperatures were relatively stable in the decades leading up to the 1970 s, even as fossil-fuel consumption shot up. Then industrialized countries began curbing $\mathrm{SO}_{2}$ and $\mathrm{NO}_{x}$ to reduce acid rain and protect public health - and temperatures increased rapidly. The latest work, led by Drew Shindell at NASA's Goddard Institute for Space Studies in New York, looks at how the climate effects of air pollutants and greenhouse gases could play out over time and geography.

The study analysed a suite of scenarios for the years 2000 to 2080 , mixing annual rates of powerplant growth from $5 \%$ to $10 \%$ with various controls on $\mathrm{SO}_{2}$ and $\mathrm{NO}_{x}$ pollution. $\mathrm{SO}_{2}$ is a precursor to sulphate aerosols and dominates the cooling effect, which varies depending on when plants adopt pollution controls. The sooner controls are put in place, the sooner the warming potential of $\mathrm{CO}_{2}$ kicks in.
In one scenario assuming rapid growth in coal power with pollution controls phased in between 2040 and 2060, the effect of aerosols from the plants outweighs the effect of their $\mathrm{CO}_{2}$ until the year 2046, when the $\mathrm{CO}_{2}$ effect catches up and then overtakes aerosols. But the effect isn't uniform: the $\mathrm{SO}_{2}$ emissions produce a net cooling across much of the Northern Hemisphere. The Southern Hemisphere and the Arctic see fewer aerosols and, because $\mathrm{CO}_{2}$ has global effects, they exhibit net warming.

How quickly China and India will move to clean up their coal emissions is unclear. In the past few years China has been aggressively installing $\mathrm{SO}_{2}$ scrubbers on many of its power plants in an attempt to improve air quality and protect public health. But some experts have questioned whether those scrubbers are being used properly - or even turned on. Jeff Tollefson 